\title{
MMTV-Wnt1 and $-\Delta$ N89ß-Catenin Induce Canonical Signaling in Distinct Progenitors and Differentially Activate Hedgehog Signaling within Mammary Tumors
}

\author{
Brigitte Teissedre', Alicia Pinderhughes ${ }^{9}$, Angela Incassati, Sarah J. Hatsell, Minoti Hiremath, Pamela \\ Cowin*
}

Departments of Cell Biology and Dermatology, New York University School of Medicine, New York, New York, United States of America

\begin{abstract}
Canonical Wnt/ $\beta$-catenin signaling regulates stem/progenitor cells and, when perturbed, induces many human cancers. A significant proportion of human breast cancer is associated with loss of secreted Wnt antagonists and mice expressing MMTVWnt 1 and MMTV- $\Delta$ N89 $\beta$-catenin develop mammary adenocarcinomas. Many studies have assumed these mouse models of breast cancer to be equivalent. Here we show that MMTV-Wnt1 and MMTV- $\Delta$ N89 $\beta$-catenin transgenes induce tumors with different phenotypes. Using axin2/conductin reporter genes we show that MMTV-Wnt1 and MMTV- $\Delta N 89 \beta$-catenin activate canonical Wnt signaling within distinct cell-types. $\Delta \mathrm{N} 89 \beta$-catenin activated signaling within a luminal subpopulation scattered along ducts that exhibited a K18 ${ }^{+} \mathrm{ER}^{-} \mathrm{PR}{ }^{-} \mathrm{CD} 24^{\text {high }} \mathrm{CD} 49 \mathrm{f}^{\text {low }}$ profile and progenitor properties. In contrast, MMTV-Wnt 1 induced canonical signaling in $\mathrm{K}_{4} 4^{+}$basal cells with CD24/CD49f profiles characteristic of two distinct stem/progenitor cell-types. MMTVWnt1 produced additional profound effects on multiple cell-types that correlated with focal activation of the Hedgehog pathway. We document that large melanocytic nevi are a hitherto unreported hallmark of early hyperplastic Wnt $1 \mathrm{glands}$. These nevi formed along the primary mammary ducts and were associated with Hedgehog pathway activity within a subset of melanocytes and surrounding stroma. Hh pathway activity also occurred within tumor-associated stromal and $\mathrm{K} 14^{+} / \mathrm{p} 63^{+}$ subpopulations in a manner correlated with Wnt1 tumor onset. These data show MMTV-Wnt1 and MMTV- $\Delta$ N89 $\beta$-catenin induce canonical signaling in distinct progenitors and that Hedgehog pathway activation is linked to melanocytic nevi and mammary tumor onset arising from excess Wnt1 ligand. They further suggest that Hedgehog pathway activation maybe a critical component and useful indicator of breast tumors arising from unopposed Wnt 1 ligand.
\end{abstract}

Citation: Teissedre B, Pinderhughes A, Incassati A, Hatsell SJ, Hiremath M, et al. (2009) MMTV-Wnt1 and - $\Delta$ N89 $\beta$-Catenin Induce Canonical Signaling in Distinct Progenitors and Differentially Activate Hedgehog Signaling within Mammary Tumors. PLoS ONE 4(2): e4537. doi:10.1371/journal.pone.0004537

Editor: Syed A. Aziz, Health Canada, Canada

Received December 11, 2008; Accepted January 5, 2009; Published February 19, 2009

Copyright: (c) 2009 Teissedre et al. This is an open-access article distributed under the terms of the Creative Commons Attribution License, which permits unrestricted use, distribution, and reproduction in any medium, provided the original author and source are credited.

Funding: This work was supported by NIH-R01-GM47429, Susan G. Komen Foundation BCTR0504557 and by training awards from Philip Morris International, Kimmel Foundation, and DOD-BC074763, Susan G Komen PDF0707333, NIH-NRSA F31CA119940-02 and F31CA130137. The funders had no role in study design data collection and analysis, decision to publish, or preparation of the manuscript.

Competing Interests: The authors have declared that no competing interests exist.

*E-mail: cowinp01@nyumc.org

9 These authors contributed equally to this work.

\section{Introduction}

Wnts are a family of secreted proteins that regulate tissue patterning and homeostasis. The canonical Wnt pathway operates by inhibiting proteolysis of cytoplasmic $\beta$-catenin, which enters the nucleus and regulates transcription through Lef/Tcf DNA binding partners. It is well documented that canonical Wnt/ $\beta$-catenin signaling is required for the viability of particular stem cells, and forced activation of this pathway can expand stem/progenitors, alter cell fate and induce tumorigenesis [1-3].

Multiple lines of evidence demonstrate roles for Wnt/ $\beta$-catenin signaling in mammary development and breast cancer $[4,5]$. Multiple Wnts are expressed throughout mammary development. Mice expressing Wnt inhibitors, or deficient in Lef-1, show defective embryonic mammary development, and loss of the Wnt coreceptor, LRP5/6, impairs postnatal development [6-9]. Both loss- and gainof-function studies have established roles for Wnt4 and Wnt5a in ductal side branching and for $\beta$-catenin signaling in alveologenesis and survival [10-15]. Although $\beta$-catenin mutations have not been found in breast cancer, pathway activation due to loss of the extracellular Wnt antagonist, sFRP1, is a frequent event $[4,5,16]$. In mice, expression of $W n t 1$ and stabilized $\beta$-catenin $(\Delta \mathrm{N} 89 \beta$-catenin) under the control of the mouse mammary tumor virus LTR (MMTV) induces precocious mammary development and adenocarcinoma formation $[13,17,18]$. Tumors induced by both transgenes are enriched in side-population content and cells expressing primitive cell markers that exhibit greater colony-forming capabilities. Collectively, these studies have lead to the hypothesis that canonical Wnt/ $\beta$-catenin signaling predisposes mice to breast cancer by amplifying stem/progenitor populations [4,18-22].

Recent studies have shown that only a minor subpopulation of human breast tumor cells can propagate tumors [23]. Such tumorinitiating cells (TICs) share with normal stem cells the ability to self-renew and to generate differentiated progeny. Although commonly referred to as cancer stem cells (CSCs), it is unclear whether TICs derive from stem cells and/or from less potent progeny that acquire stem cell properties during transformation. Moreover, the contribution of distinct cancer stem cells to breast cancer heterogeneity remains obscure. Candidate mammary stem and progenitor populations have been identified by ultrastructural 
features, expression of stem cell antigen-1 (Sca-1), and ability to efflux Hoechst 33342 dyes, which upon cell sorting generates a side-population [24-26]. Recent sorting studies of murine mammary cells have identified a subpopulation, with a lineagedepleted $\left(\mathrm{Lin}^{-}\right) / \mathrm{CD} 24^{\text {low }} / \mathrm{CD} 29 / 49 \mathrm{f}^{\mathrm{high}} / \mathrm{Sca}^{-}{ }^{-} /$keratin $(\mathrm{K}) 14^{+}$ profile, that are enriched in "mammary repopulating units" (MRUs), which have a parent-progeny relationship with a second $\mathrm{Lin}^{-} / \mathrm{CD} 24^{\text {high }} / \mathrm{CD} 29 / 49 \mathrm{f}^{\text {low }}$ subpopulation of alveolar-limited progenitors expressing a predominantly luminal $\mathrm{K}_{1} 8^{+}$profile $[21,27]$. Other studies have described luminal progenitor populations with $\mathrm{CD} 24^{\text {high }} / \mathrm{CD} 133^{-} / \mathrm{K}_{1} 8^{+}$and $\mathrm{Lin}^{-} / \mathrm{CD} 24^{+} /$ $\mathrm{CD} 29^{\text {low }} \mathrm{CD} 1^{+} \mathrm{K} 14^{+}$profiles $[28,29]$. A study on human breast strongly supports the concept of a multipotent stem cell located within a ductal luminal niche that expresses multiple keratins [30].

Recently the connection between the physiological role of Wnt signaling in stem cells and its capacity to induce cancer when upregulated has been exploited to identify intestinal stem cells by virtue of their expression of a Wnt-responsive gene, Lgr5, that was initially found to be upregulated in colonic tumors [31]. This study suggests that identifying cell-types that respond to Wnt signaling may be an alternative route to identify and illuminate the relationship between mammary stem/progenitor cells and cancer stem cells. With this aim in mind, we employed Wnt-responsive conductin/Axin2 reporter genes to identify and isolate cells showing transcriptional response to expression of MMTV$\Delta$ N89 $\beta$-catenin and MMTV-Wntl transgenes. Our results show that these transgenes lead to activation of the canonical Wnt pathway in distinct cell-types displaying progenitor and stem cell characteristics and induce tumors with different phenotypes. A further source of disparity between these tumors arises from the unique ability of Wntl to influence multiple cells types within the gland. We show that these profound effects correlate with focal induction of Hedgehog $(\mathrm{Hh})$ pathway activity within subpopula-

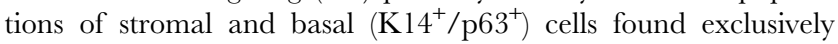
within the Wnt-1 tumor microenvironment, as well as, in and around melanocytic hyperplastic nevi, which form a hallmark of all MMTV-Wntl mammary glands. These data show that $\mathrm{Hh}$ pathway activation is linked to Wnt-1-induced mammary tumor onset and nevi formation and suggest that Hedgehog pathway activation maybe a critical component and useful marker of breast tumors arising from unopposed Wntl ligand.

\section{Results}

\section{MMTV-Wnt1 and MMTV- $\Delta$ N89 $\beta$-catenin show phenotypic disparity}

MMTV-Wnt1 and MMTV- $\Delta$ N89 $\beta$-catenin induce precocious mammary development and adenocarcinoma formation [13,17]. However, the two types of transgenic lines differ in their lactational competence $[13,17]$. This functional disparity led us to examine the respective mammary phenotypes for morphological differences that may yield insight into the corresponding pathobiological mechanisms. In glands expressing MMTV- $\Delta$ N89 $\beta$-catenin acini budded directly from ductal borders (Fig. 1A), and were associated with spindle-shaped $\mathrm{K}_{14}{ }^{+}$basal cells (Fig. 1B), which resembled flattened myoepithelial cells of normal alveoli. However, the ducts, visualized by a ductal luminal cell marker, latent transforming growth factor- $\beta$ binding protein (LTBP)1-lacZ (Fig. 1C, E), were similar to those of controls (Fig. 1D). In contrast, MMTV-Wntl expression induced pronounced ductal changes, including hyperbranching (Fig. 1F). These hyperplasias were encased in a coherent thick $\mathrm{K}_{1} 4^{+}$cell layer (Fig. 1G), which resembled the myoepithelial layers ensheathing normal ducts. Ductal contortion (Fig. 1H), cyst formation (Fig. 1I), and lumenal occlusions (Fig. 1J) were prominent. The cellular composition and architecture of the tumors induced by the transgenes also showed subtle but important differences. Tumors from MMTV- $\Delta$ N89 $\beta$-catenin mice contained many more $\mathrm{K} 18^{+}$ than $\mathrm{K}^{+} 4^{+}$cells and were hormone receptor-negative (Fig. 2A-C). These frequently retained well-differentiated acinar polarization, with luminal cells expressing apical mucin (MUC) 1 (Fig. 2D) and showing basal deposition of laminin V (Fig. 2E). Stromal cells, detected by vimentin antibodies, were sparse (Fig. 2F). Tumors from MMTV-Wntl mice displayed bi-layered papillary arrays of cells, showed an equal ratio of $\mathrm{K} 14^{+} / \mathrm{K}_{1} 8^{+}$cells and expressed hormone receptors (Fig. 2G-I). They showed loss of polarized organization; indicated by reduced MUC1 expression (Fig. 2J), frequent laminin V accumulation in patches (Fig. 2K), and stromal hypertrophy (Fig. 2L). In conclusion, expression of MMTV- $\Delta$ N89 $\beta$-catenin induced expansion of hormone-receptor-negative, $\mathrm{K} 18^{+}$cells, which maintained alveolar features and were lactationally competent, whereas MMTV-Wntl expression significantly expanded $\mathrm{K}_{1} 4^{+}$cells in addition to both hormone-receptor-positive and -negative $\mathrm{K} 18^{+}$cells and lead to perturbed ductal formation and lactational failure.

\section{MMTV-Wnt 1 and MMTV- $\Delta$ N89 $\beta$-catenin activate the canonical signaling pathway within different cell-types}

Based on the disparate phenotypes described above, we hypothesized that $\Delta N 89 \beta$-catenin and Wntl transform different progenitors. The MMTV-LTR is expressed within mammary luminal epithelium. Therefore $\beta$-catenin's transcriptional effects are restricted to cells within this layer, whereas Wntl, a secreted factor, can act in an autocrine and/or paracrine fashion in any cells that expresses a Wntl receptor. To determine which cell-types respond to the expression of these transgenes via activation of the canonical pathway, we crossed MMTV- $\Delta$ N89 $\beta$-catenin and MMTV-Wntl mice to Axin2-d2EGFP transgenic and Conductin $^{+/ l z}$ heterozygous lac $z$ knock-in reporter lines. The Axin $2 /$ Conductin gene is expressed constitutively in response to canonical Wnt/ $\beta$-catenin signaling and its product negatively regulates the pathway [32,33]. Despite uniform expression of MMTV- $\Delta$ N89 $\beta$-catenin within the luminal epithelium [13], transcriptional response, detected by Conductin-lacz reporter expression, was restricted to a subpopulation of luminal cells scattered along secondary and tertiary ducts (Fig. 3A). In early hyperplasia, approximately one luminal cell per alveolus expressed Conductin-lacZ (Fig. 3B) and these cells became more prominent as the hyperplasia increased but the main ducts remained devoid of $\beta$-catenin signaling (Fig. 3C). In contrast, mammary glands from MMTV-Wntl mice showed a strikingly uniform Conductin-lacZ expression pattern along the entire mammary ductal system (Fig. 3D and F) and the reporter was found exclusively within basal cells (Fig. 3E). These distinct cellular patterns of transcriptional response were maintained in tumors (Fig. 4A-F). In tumors from MMTV- $\Delta$ N89 $\beta$-catenin mice, Conductinlac Z was expressed within cells expressing the luminal marker K18 and absent from $\mathrm{K}_{1} 4^{+}$cells (Fig. 4A-C). Wntl tumors showed the converse expression pattern; Conductin-lacZ expressing cells were restricted to a single $\mathrm{K} 14^{+} / \mathrm{K} 18^{-}$layer of the bilayered papillary tumors (Fig. 4D-F). In conclusion, these data show that a subset of $\mathrm{K}_{18}{ }^{+}$cells respond to $\Delta \mathrm{N} 89 \beta$-catenin. $\mathrm{K} 18^{+}$luminal epithelial cells from MMTV-Wntl mice fail to respond, suggesting they lack a Wntl receptor, or that autocrine canonical pathway activity is suppressed by non-canonical antagonism within this cell-type. In contrast, $\mathrm{K} 14^{+}$cells show a robust paracrine canonical response to Wntl.

\section{MMTV- $\Delta$ N89 $\beta$-catenin and MMTV-Wnt1 amplify cells with distinct CD24/49f stem/progenitor profiles}

To further compare the cell-type composition of tumors, we isolated mammary epithelial cells (MECs) from tumors of MMTV- 

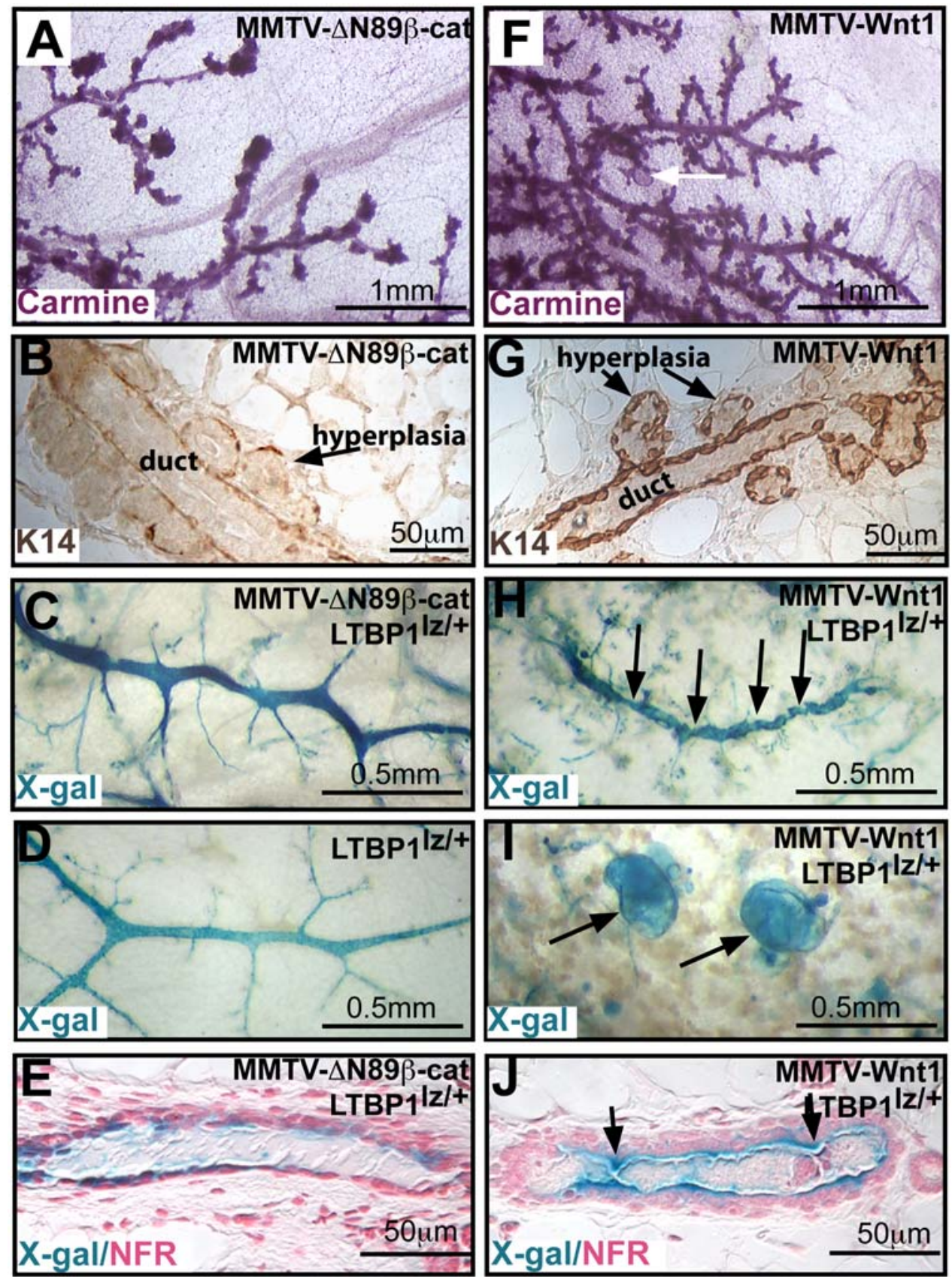

Figure 1. Phenotypic differences between MMTV-AN89ß-catenin and MMTV-Wnt1 hyperplasias. Mammary glands from 12 week-old virgin MMTV- $\Delta$ N89 $\beta$-catenin (MMTV- $\Delta$ N89 $\beta$-cat) (A-E) and MMTV-Wnt1 (F-J) mice. Mammary whole mounts stained with carmine (A, F) or X-Gal (C, D, $H$, I). Sections stained immunohistochemically with anti-K14 antibodies to detect the basal cells $(B, G)$ or with X-Gal to detect luminal LTBP1-lacZ expression and nuclear fast red $(E, J)$. Note mammary glands from MMTV- $\Delta$ N89 $\beta$-catenin mice show alveolar hyperplasia (A, B) but their ductal system (C, E) is comparable to controls (D). Mammary glands from MMTV-Wnt1 mice show hyperbranching (F), K14 ${ }^{+}$cell ensheathment (G), ductal constriction (arrows $\mathrm{H}, \mathrm{J}$ ) and large ductal cysts (arrows $\mathrm{F}, \mathrm{I}$ ).

doi:10.1371/journal.pone.0004537.g001

$\Delta \mathrm{N} 89 \beta$-catenin and MMTV-Wntl mice and investigated their expression of CD24 and CD49f. These markers separate MECs from wt mice into two roughly equal populations by flow cytometry: CD24 ${ }^{\text {high }} \mathrm{CD} 49 \mathrm{f}^{\text {dow }}$ and CD24 ${ }^{\text {low }} \mathrm{CD} 49 \mathrm{f}^{\text {high }}$ (Fig. 5G). The most rightward and upward shifted cells within each of these populations have been reported to be enriched in colony-forming cell (CFC) comprising alveolar progenitors and multipotent mammary repopulating units (MRUs), respectively [27]. $\Delta$ N89 $\beta$ catenin tumors were enriched for CD24 ${ }^{\text {high }}$ CD $49 f^{\text {ow }}$ MECs
(Fig. 5A) $\left(62 \%\right.$ compared to $37 \%$ CD $\left.24^{\text {low }} \mathrm{CD} 49 \mathrm{f}^{\text {high }}\right)$. In contrast, Wntl tumors were enriched for CD24 ${ }^{\text {low }}$ CD $49 f^{\text {high }}$ MECs (Fig. 5D) (65\%, compared to $35 \%$ CD24 $\left.4^{\text {high }} \mathrm{CD} 49 \mathrm{f}^{\text {low }}\right)$. To characterize cells undergoing an active transcriptional response to expression of these transgenes, we crossed MMTV-Wntl and MMTV- $\Delta$ N89 $\beta$-catenin lines to the Axin2-d2EGFP reporter mouse, isolated tumor MECs from the bitransgenic progeny and analyzed them for enhanced green fluorescent protein (EGFP) and CD24/CD49f expression by flow cytometry. In contrast to the 


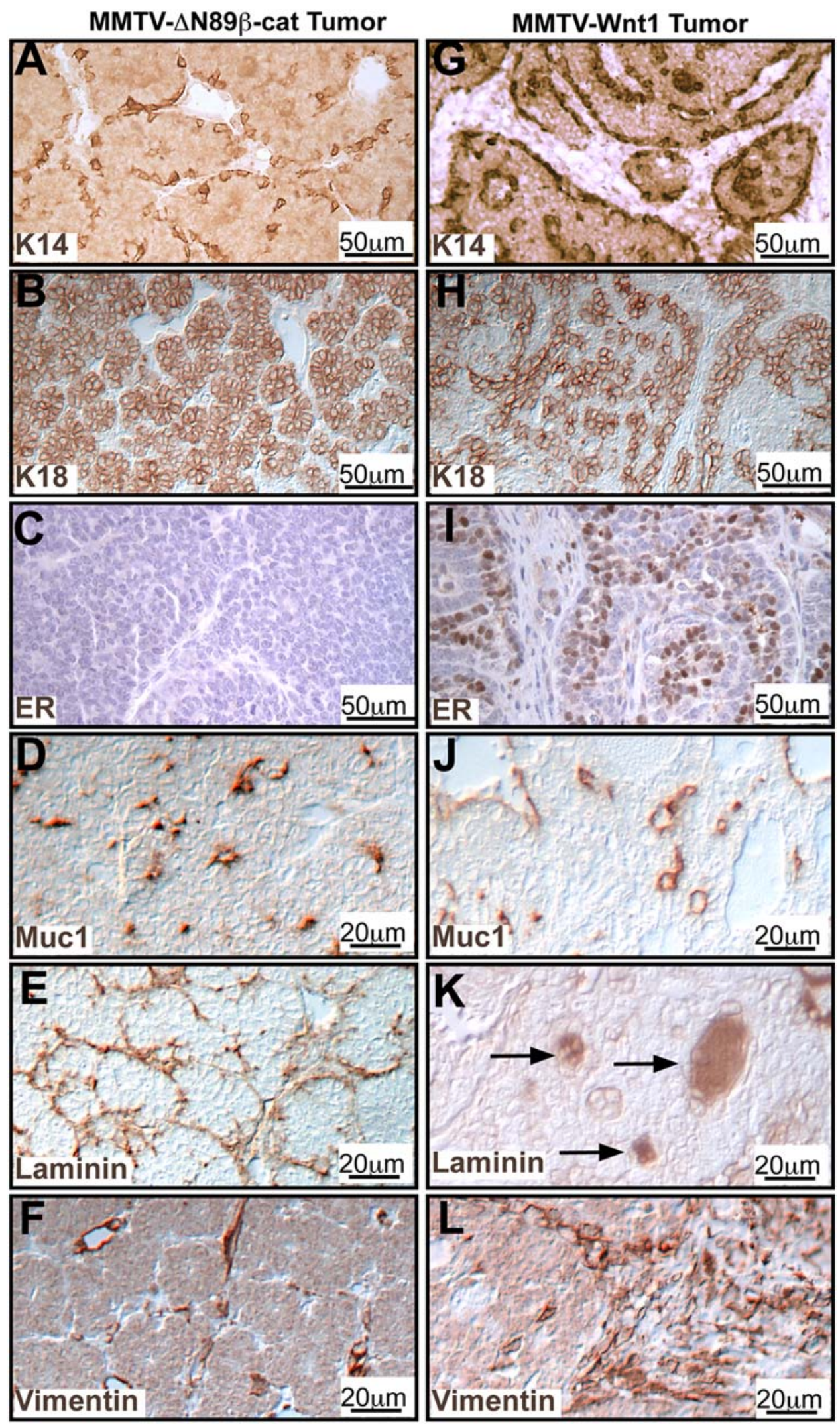

Figure 2. MMTV- $\Delta$ N89 $\beta$-catenin and MMTV-Wnt1 tumors have distinct cellular composition. Tumor sections from MMTV- $\Delta N 89 \beta-c a t e n i n$ (MMTV- $\Delta$ N89ק-cat) (A-F) and MMTV-Wnt1 (G-L) stained with antibodies as indicated against K14, K18, estrogen receptor (ER), MUC1, laminin, and vimentin. Note distorted laminin deposition (Arrows in K) and stromal hyperplasia (L). doi:10.1371/journal.pone.0004537.g002 


\section{Conductin $+/ / z / M M T V-\Delta N 89 \beta-c a t$}
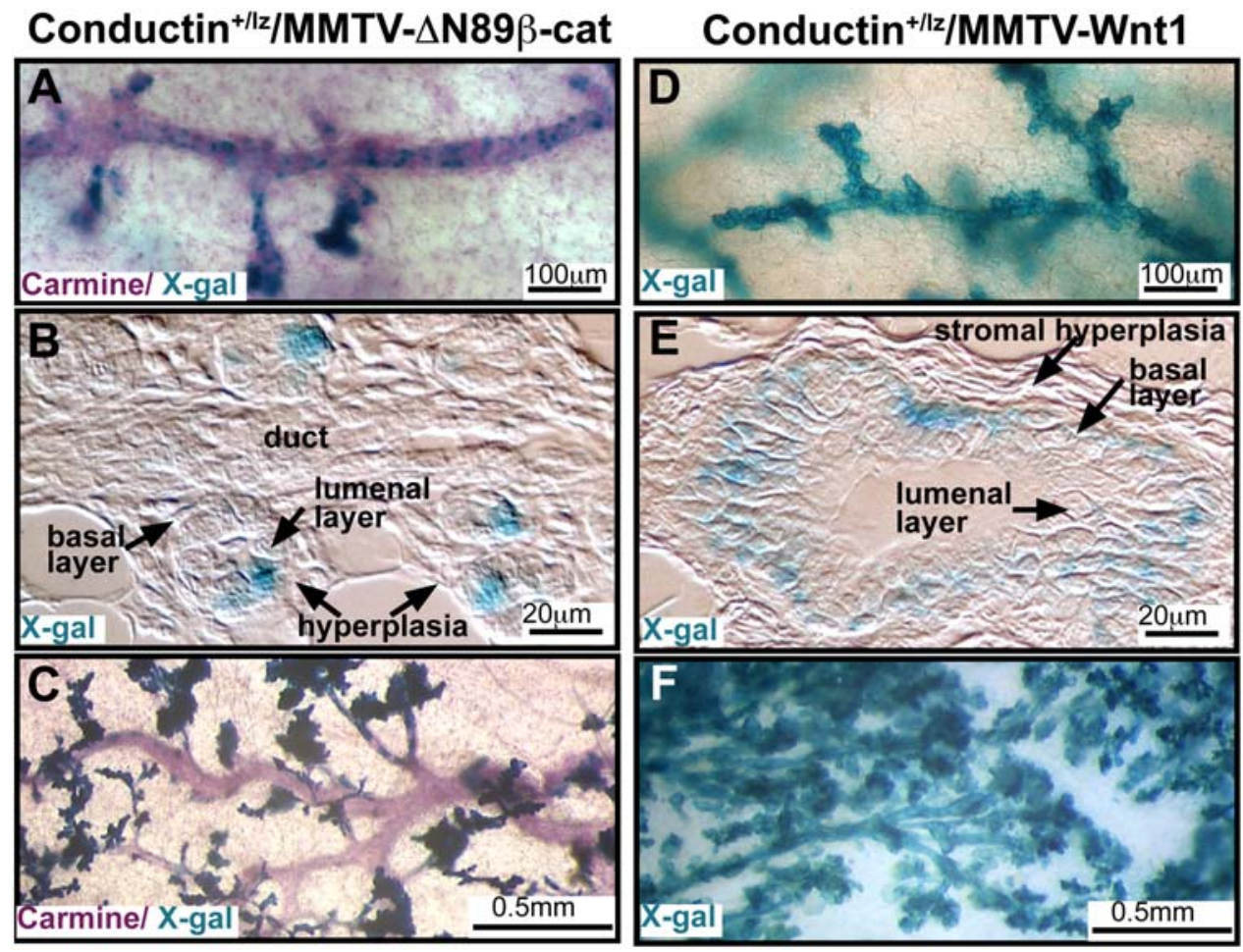

Figure 3. Conductin-lacZ is expressed in $\mathrm{K}^{18^{+}}$subpopulations in MMTV- $\mathrm{N} 89 \beta-$-catenin and $\mathrm{K} 14^{+}$subpopulations in MMTV-Wnt1

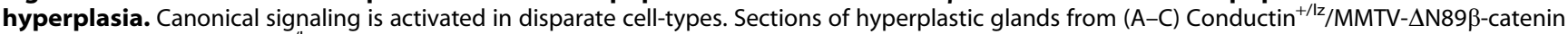
mice, and (D-F) Conductin ${ }^{+/ 1 z} /$ MMTV-Wnt1 mice stained with X-gal to detect Conductin-lacZ expression (blue), a reporter of canonical Wnt signaling, and stained with antibodies against K14 and K18 (brown) as indicated. Note the stromal hypertrophy surrounding Wnt1 hyperplastic ducts (E). doi:10.1371/journal.pone.0004537.g003

even distribution of $\mathrm{EGFP}^{-}$cells from MMTV- $\Delta \mathrm{N} 89 \beta$-catenin mice between the two major CD24/CD49f cell populations

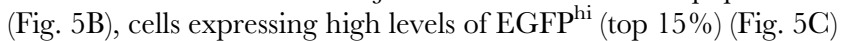
fell exclusively within the CD $24^{\text {high }}$ CD $49 f^{\text {fow }}$ subpopulation and showed an upward rightward shift in mean fluorescence intensity, suggestive of CFCs. To test the functional significance of these observations, we compared the ability of $\mathrm{EGFP}^{+}, \mathrm{EGFP}^{-}$and total MECs from MMTV- $\Delta$ N89 $\beta$-catenin mice to form colonies at limiting dilution. $\mathrm{EGFP}^{+}$cells showed 3-5-fold greater colony forming efficiency compared to total sorted cells, and a corresponding depletion of colony-forming efficiency was found within the $\mathrm{EGFP}^{-}$cell population (Fig. $5 \mathrm{H}$ ). Immunofluorescence analysis showed that $\mathrm{EGFP}^{+}$cells produced colonies composed of mixed progeny, with some cells expressing K8 and others K14 (Fig. 5I). We conclude that $\Delta \mathrm{N} 89 \beta$-catenin signaling cells within tumors show marker expression profiles that mirror those of CFC alveolar progenitors from normal gland and are bipotent, giving rise to luminal and basal cell types in vitro. In contrast, EGFP (Fig 5E) and $\mathrm{EGFP}^{\text {hi }}$ (Fig. 5F) cells from MMTV-Wntl mice were distributed in both CD24/CD49f subpopulations. However, the EGFP $^{\text {hi }}$ (Fig. 5F) cells were skewed to the right side of the CD $24{ }^{\text {high }} \mathrm{CD} 49 \mathrm{f}^{\text {low }}$ population and those within the CD $24^{\text {low }}$ CD $49 \mathrm{f}^{\text {high }}$ subpopulation showed an upward rightward shift. These shifts are consistent with the profiles of $\mathrm{CD} 61^{+} / \mathrm{K} 14^{+}$ progenitors and of MRUs that have been shown in previous reports to have CSC capabilities [22,27,28,34].

\section{MMTV-Wnt1 expression induces Hh pathway activation within the tumor}

Wnt and Hh pathways are frequently coupled in the cross-talk between stem cells and their stromal niche and an essential linkage between these pathways has been documented recently in basal cell skin cancer [35]. To determine if the $\mathrm{Hh}$ pathway was activated in hyperplasia and tumors of MMTV-Wntl and MMTV- $\Delta$ N89 $\beta$-catenin mice, we crossed these lines to $\mathrm{Gli1}^{+/ l z}$ reporter mice. Hh signals are transduced by members of the Gli protein family, (Glil-3). Glil is both a transcriptional target gene and positive amplifier of the pathway. Its expression is strictly dependent upon Hh signaling and thus provides a reliable reporter of Hh pathway activation [36]. Hh pathway activity is repressed within the mammary tree of non-transgenic Gli $^{+/ l z}$ control glands and Gli1-lacz reporter expression was restricted to lymphatics (Fig. 6A) [37]. Similarly, hyperplasia and tumors from MMTV$\Delta \mathrm{N} 89 \beta$-catenin; Gli1 $^{+/ l z}$ mice showed no evidence of Gli1-lacZ expression within the epithelial and stromal compartments (Fig. 6B). In contrast, tumors derived from MMTV-Wntl;Gli1 ${ }^{+/ l z}$ mice showed robust Gli1-lacZ expression within stromal cells and a minor subset of basal cell-types, some of which expressed p63 (Fig. 6C, D). Importantly, this reporter expression was restricted to the tumor bed and not observed in hyperplasia (Fig. 6E). These data demonstrate that Wntl expression leads to aberrant Hh pathway activation within the Wntl tumor microenvironment.

MMTV-Wnt1 expression results in dramatic accumulation and differentiation of melanocytes along the lactiferous sinus and primary ducts

Another striking linkage between $\mathrm{Hh}$ pathway activation and MMTV-Wntl expression was found in melanocytic hyperplasia under the nipple region (Fig. 6E box). A hallmark of mammary glands from pigmented MMTV-Wntl mice was accumulation of melanin around the trunk and primary mammary branches (Fig. 7A, E). Large black aggregates emanating from the nipple 


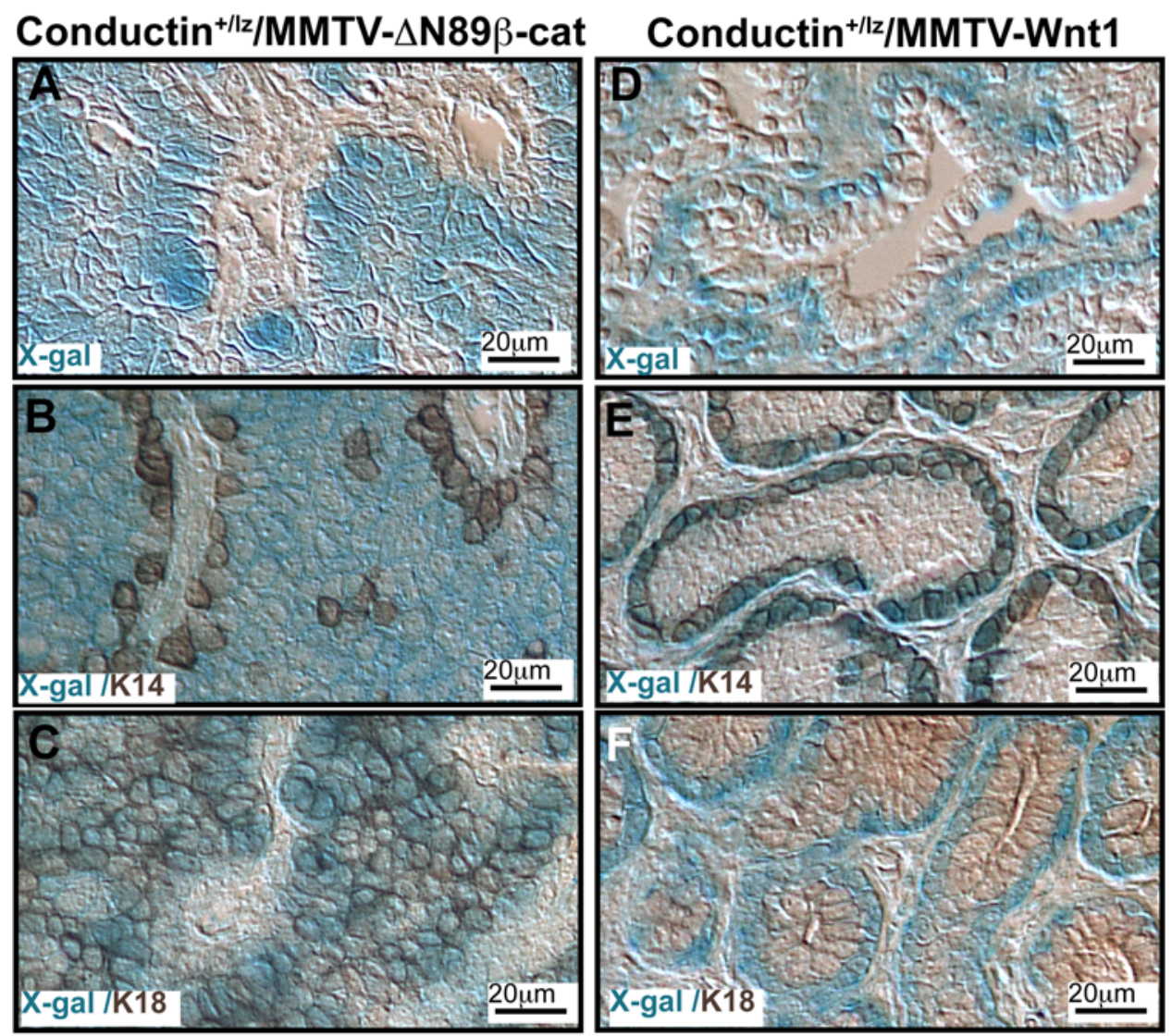

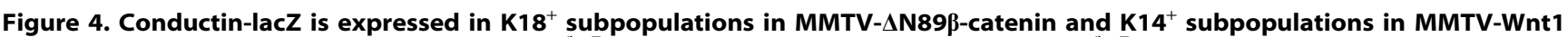
tumors. Sections of tumors from (A-C) Conductin ${ }^{+/ l a c Z / M M T V-~} \Delta N 89 \beta$-catenin, and (D-F) Conductin ${ }^{+/ l a c Z / M M T V-W n t 1 ~ m i c e ~ s t a i n e d ~ w i t h ~ X-g a l ~ t o ~}$ detect Conductin-lacZ expression (blue), a reporter of canonical Wnt signaling, and stained immunohistochemically with antibodies against K14 and K18 (brown) as indicated.

doi:10.1371/journal.pone.0004537.g004

mesenchyme formed spider-like extensions into the mammary fatpad that could be observed by eye $(\mathrm{n}=29)$. These were absent from mammary glands of pigmented wt $(\mathrm{n}=17)$ and MMTV$\Delta$ N89 $\beta$-catenin $(n=5)$ mice and from all albino mice regardless of genotype ( $\mathrm{n}=34 \mathrm{Wnt} ; \mathrm{n}=10 \Delta \mathrm{N} 89 \beta$-catenin; $\mathrm{n}=13$ wild-type). Mammary whole-mounts (Fig. 7A) and sections (Fig. 7B-C) from pigmented MMTV-Wntl mice revealed melanin deposition within the basal layer, stromal cells and occasionally within the secretions of the primary lactiferous ducts. However, immunohistochemical analysis with antibodies against the S100 $\beta$ melanocyte marker revealed large numbers of dendritic melanocytes in albino as well as pigmented Wntl mice (Fig. 7C, G). We conclude that Wnt-1 expression leads to migration, accumulation and differentiation of melanocytes along the primary mammary ducts and that these cells are not present in MMTV $\Delta$ N89 $\beta$-catenin and $w t$ mice.

To investigate whether Wntl induces these effects on melanocytes through canonical signaling and/or involves $\mathrm{Hh}$ pathway activation, we examined whole mounts of bitransgenic MMTV-Wnt1; Conductin $^{+/ l z}$ and MMTV-Wnt1;Gli1 ${ }^{+/ l z}$ mice for reporter expression. Conductin-Gal was restricted to basal cells and absent from the underlying stroma where melanocytes reside (Fig. 7F). In contrast, prominent Gli1-lacZ reporter expression was observed exclusively around the primary ducts of all MMTVWnt $;$ Gli1 ${ }^{+/ l z}$ mice $(\mathrm{n}=8)$ (Fig. 7D, E), colocalizing with the melanotic aggregates of pigmented MMTV-Wnt1;Gli1 ${ }^{+/ l z}$ mice $(\mathrm{n}=4)$ (Fig. 7E) and within a subset melanocytes identified by S100 $\beta$ staining and many neighboring fibroblasts in albino
MMTV-Wnt1;Gli1 ${ }^{+/ l z}$ mice $(\mathrm{n}=4)$ (Fig. 7D, G). Gli1-lacZ expression was absent from corresponding regions of MMTV$\Delta$ N89ß-catenin;Gli1 ${ }^{+/ l z}(\mathrm{n}=4)$ and control Gli1 ${ }^{+/ l z}(\mathrm{n}=2)$ glands. We conclude that MMTV-Wntl expression induces aberrant melanocyte accumulation and differentiation within the fatpad and this event does not involve canonical pathways but correlates with robust $\mathrm{Hh}$ pathway activity within the stroma and a minor melanocyte subpopulation.

\section{Discussion}

The key findings of this study are that MMTV- $\Delta$ N89 $\beta$-catenin and MMTV-Wntl induce distinct tumors, activate canonical signaling in disparate cell-types, and MMTV-Wntl alone results in focal $\mathrm{Hh}$ pathway activity within the mammary tumor microenvironment and in and around melanocytic hyperplasia.

\section{MMTV- $\Delta$ N89 $\beta$-catenin and MMTV-Wnt1 induce canonical} signaling in distinct cell-types

Previous studies have shown that MMTV- $\Delta$ N89 $\beta$-catenin and MMTV-Wntl tumors express primitive cell markers and are enriched in cell populations with stem/progenitor features [19$21,34]$. Our work extends these findings by identifying the celltypes that undergo a canonical response to transgene expression. Despite uniform MMTV- $\Delta$ N89 $\beta$-catenin expression within the luminal epithelium [13], our results show that a specific subset of luminal cells express the transcriptional reporter, Conductin-lacz. 


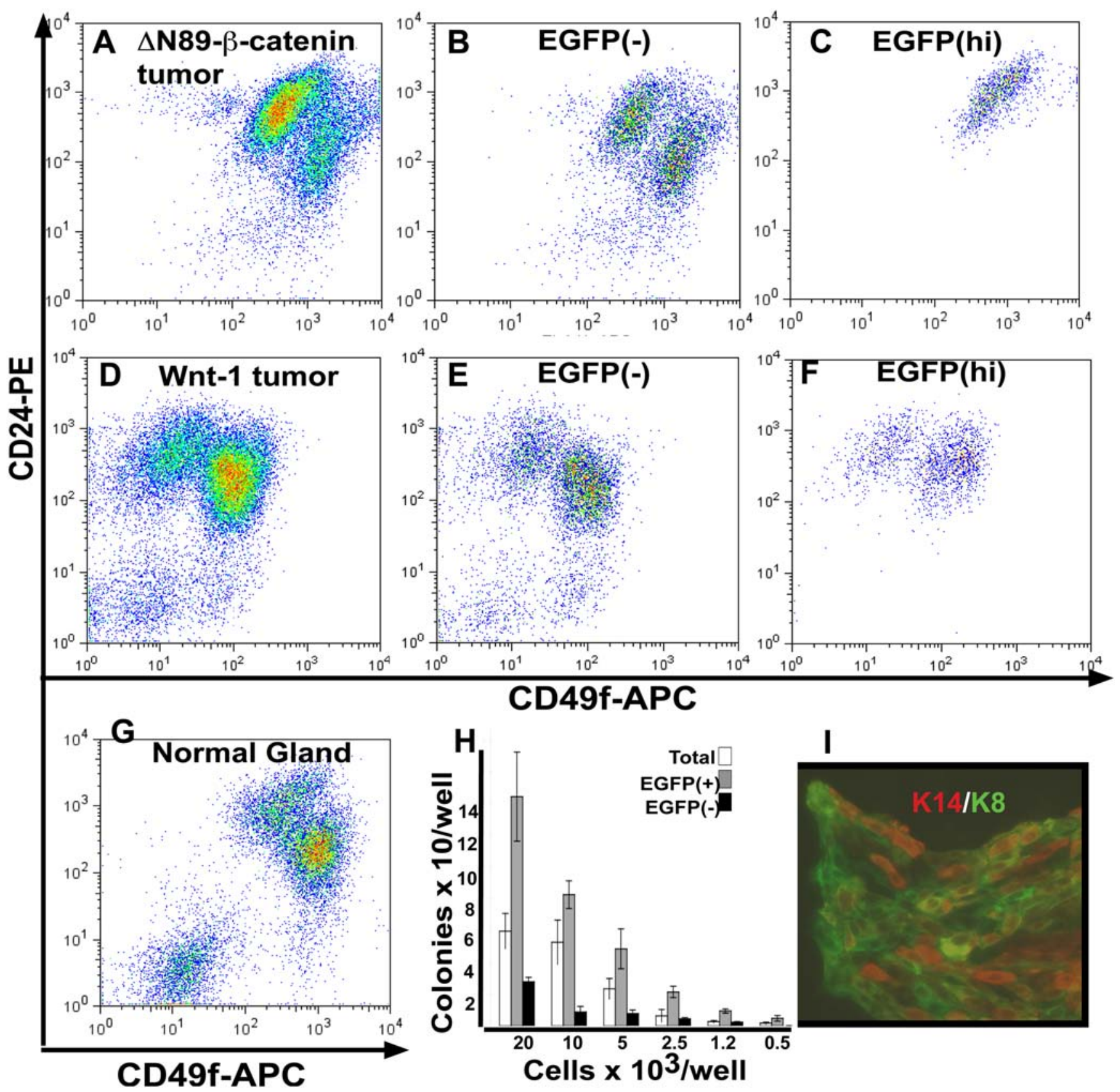

Figure 5. MMTV- $\Delta$ N89ק-catenin and MMTV-Wnt1 tumors show expansion of distinct CD24/CD49f cell populations. CD24/CD49f marker profile of (A) total, (B) EGFP- and (C) EGFPhi cells from MMTV- $\Delta$ N89 $\beta$-catenin tumors. Note the enrichment and upward shift of EGFPhi cells within the CD24 high/CD49flow subpopulation. CD24/CD49f marker profile of (D) total, (E) EGFP- and (F) EGFPhi cells from MMTV-Wnt1 tumors. Note EGFPhi cells are shifted rightward within the CD24 ${ }^{\text {high }} / C D 49 f^{\text {low }}$ subpopulation and upward within the CD24 $4^{\text {low }} / C D 49 f^{\text {high }}$ subpopulation. CD24/CD49f marker profile of (G) total cells from a wt littermate. (H) EGFP ${ }^{+}$cells from MMTV- $\Delta$ N89 $\beta$-catenin tumors show higher colony forming efficiency than $\mathrm{EGFP}^{(-)}$and total sorted cells. (I) Immunofluorescence analysis shows these EGFP ${ }^{+}$cells are generate colonies containing $\mathrm{K}^{+} 4^{+}$and $\mathrm{K}^{+}$cells. doi:10.1371/journal.pone.0004537.g005

These $\beta$-catenin-responsive cells display a hormone-receptornegative [38], K18 CD24 ${ }^{\text {high }} \mathrm{CD} 49 \mathrm{f}^{\text {ow }}$ profile, and generate colonies containing both $\mathrm{K}^{+}$and $\mathrm{K} 14^{+}$cells. Thus, they exhibit the expected location, molecular profile and functional bipotency ascribed to alveolar progenitor populations from normal mammary glands $[21,27]$. These features, in conjunction with the overwhelmingly alveolar-like phenotype of MMTV- $\Delta$ N89 $\beta$-catenin hyperplasia, strongly support the hypothesis that MMTV$\Delta \mathrm{N} 89 \beta$-catenin acinar tumors develop from expansion of alveolar progenitors, or by skewing the lineage of a bipotent alveolar/ ductal progenitor towards an alveolar fate. This concept is reminiscent of K14- $\Delta$ N80 $\beta$-catenin effects on skin appendage fate and consistent with our previous findings that known regulators of alveolar progenitor determination, expansion and differentiation influence the MMTV- $\Delta$ N89 $\beta$-catenin-phenotype $[18,38]$.

Many studies have assumed that MMTV- $\Delta$ N89 $\beta$-catenin and MMTV-Wntl exert a similar tumorigenic effect and have studied these models interchangeably. Where phenotypic differences have been noted Wntl's potential to activate non-canonical pathways has been speculated upon but not experimentally addressed. Our 

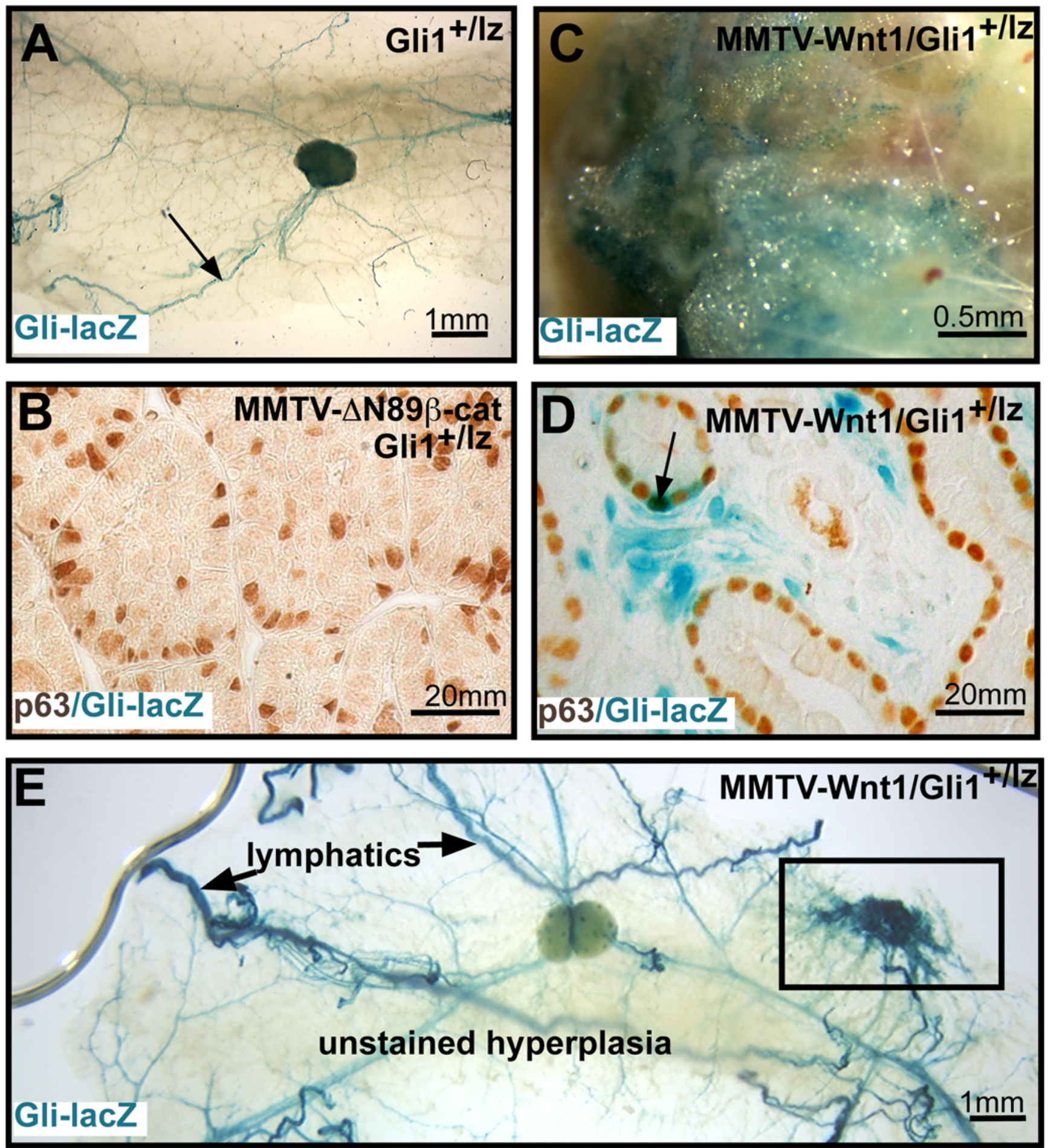

Figure 6. Hh pathway activity within the MMVT-Wnt1 tumor microenvironment. Gli1-lacZ expression is restricted to lymphatic vessels (arrow) in mammary whole mounts of (A) control Gli1 ${ }^{+/ 1 z}$ mice, and absent from tumor sections from (B) MMTV- $\Delta N 89 \beta-c a t e n i n ; G l i 1^{+/ 1 z}$ mice, but is strongly expressed in (C) MMTV-Wnt1;Gli ${ }^{+/ l z}$ tumor whole mounts. In sections of MMTV-Wnt1;Gli1 ${ }^{+/ 1 z}$ tumors (D) Gli1-lacZ expression is found within stromal cells and occasional p $^{+}$cells (arrow). (E) Hyperplastic MMTV-Wnt1;Gli1 $1^{+/ 1 z}$ mammary whole mounts from 12 week-old mice show lack of reporter expression within unstained mammary hyperplasia and restriction to lymphatics and melanocytic hyperplasia (boxed area). doi:10.1371/journal.pone.0004537.g006

results show that one definitive source of disparity between these models lies in the failure of Wntl to induce autocrine canonical signaling and its ability instead to induce a robust paracrine canonical response within a basally located $\mathrm{K} 14^{+}$cell population. Several pieces of data suggest that this Wnt1-responsive $\mathrm{K} 14^{+}$cell population consists of a stem cell or early bipotent progenitor population. First, the EGFP $^{\text {hi }}$ expressing cells within the CD2 $4^{\text {low }} \mathrm{CD} 49^{\text {high }}$ subpopulation is skewed towards higher CD49f expression, a feature associated with MRU capacity, and depleted of cells with lower CD49f expression, a feature associated 

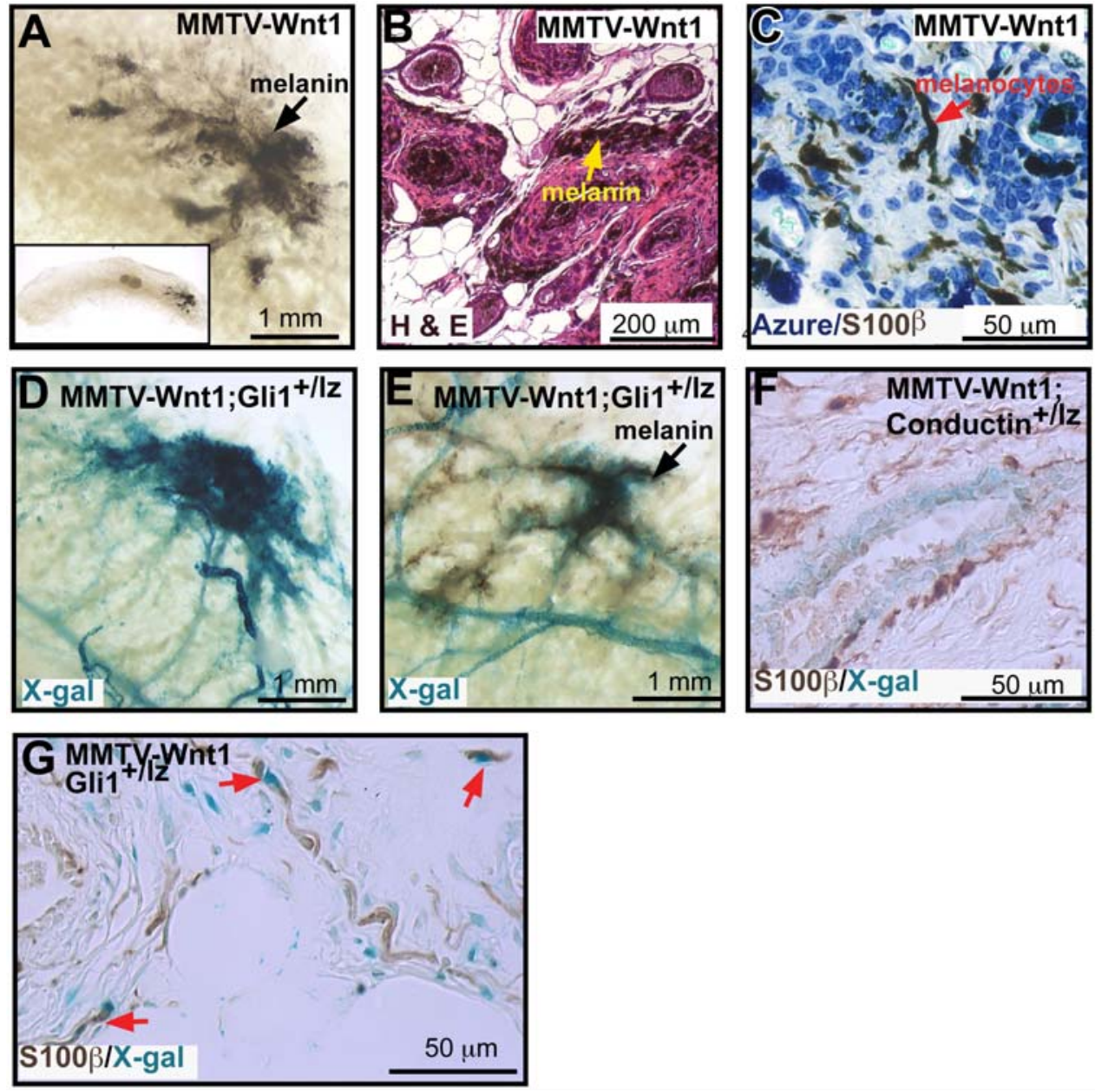

Figure 7. Melanocytic hyperplasia associated with Hh pathway activity is a hallmark of all MMTV-Wnt1 mammary glands. Mammary whole mount and sections from pigmented MMTV-Wnt1 mice show melanin deposition (A, B) and presence of melanocytes (C) detected by antiS100ß (DAKO \#Z0311). Whole mounts and sections from albino (D, G) and pigmented (E) MMTV-Wnt1;Gli1 ${ }^{1 /+}$ mice show Gli1-lacZ expression around the primary ducts localizing with melanin (E). Conductin-lacZ expression (blue) does not colocalize with S100 $\beta^{+}$(brown) (F). However a minor subset of $S 100 \beta^{+}$melanocytes (brown) (red arrows) and many of their neighboring stromal cells express the Gli1-lacZ reporter (blue) (G). doi:10.1371/journal.pone.0004537.g007

with mature myoepithelial populations [27]. $\mathrm{EGFP}^{\text {hi }}$ responding cells that segregate into the $\mathrm{CD} 24^{\text {high }} \mathrm{CD} 49^{\text {low }}$ group are also skewed rightwards and express $\mathrm{K} 14$, a profile recently ascribed to a $\mathrm{CD}_{61}{ }^{+}$bipotent progenitor population shown to have cancer stem cell properties [22,28]. Second, luminal and basal cell-types from MMTV-Wntl tumors share common genetic changes suggesting that the cell-type transformed by Wntl is a progenitor of both lineages [19]. Third, Wntl produces ductal defects (see fig 1 ) in addition to suppressing alveolar secretory differentiation [39]. Collectively, these results suggest that MMTV-Wntl induces expansion of a multipotent basal cell-type that precedes commitment to the ductal/alveolar as well as luminal/basal lineages.

Wnt1 leads to Hh pathway activity in melanocytic hyperplasia and their surrounding stroma

A further source of disparity between the MMTV- $\Delta$ N89 $\beta$ catenin and MMTV-Wntl phenotypes relates to the ability of the latter to affect additional surrounding cell-types. Of note, stromal hyperplasia (see Fig. 2L and $3 \mathrm{E}$ ) is prominent within the early hyperplastic glands and tumors of MMTV-Wntl mice but is absent from glands and tumors of MMTV- $\Delta$ N89 $\beta$-catenin mice. Another striking example is the dramatic effect on melanocyte populations. Our results show that massive melanotic deposits within the mammary fatpad are a hallmark of pigmented MMTVWntl mice and that large numbers of amelanotic melanocyte precursors accumulate around the primary lactiferous ducts of both pigmented and albino MMTV-Wntl animals. Murine melanocyte precursors normally reside in the hair follicle bulge and are not detected in the mammary fatpads of $w t$ or MMTV$\Delta$ N89 $\beta$-catenin mice. Although both canonical and non-canonical Wnt signaling have been implicated in promoting melanocyte proliferation, migration and differentiation at other body sites [40], the lack of Conductin-lacZ reporter expression within the mammary melanocytic hyperplasia strongly favors non-canonical signaling. Intriguingly, our results show a tight correlation between positive Hh signaling within a minor melanocytic subpopulation and their surrounding stromal neighbors and the massive accumulation of mobilized, differentiating melanocytes in MMTV-Wntl glands. Current literature highlights a dualistic role for $\mathrm{Hh}$ signaling in melanocyte biology [41,42]. Gli3R repression of $\mathrm{Hh}$ signaling is essential for melanoblast specification at certain body regions during development. However, consistent with our suggestion that $\mathrm{Hh}$ pathway activity is linked to melanocytic hyperplasia, one report has shown that positive $\mathrm{Hh}$ 
signaling is a critical determinant of melanoma growth and metastasis [42]. Importantly, our observations show that Wnt and Hh pathway activity are linked in the induction of these melanocytic accumulations and suggest that these pathways may contribute to pigmentary changes arising close to the nipple in association with an underlying breast carcinoma.

\section{Wnt 1 leads to Hh pathway activity within the mammary tumor microenvironment}

A second major site of focal Hh pathway activity is found within MMTV-Wntl tumors. Of note, Hh pathway activity was restricted to the Wnt-1 tumor microenvironment and was not observed within the Wnt-1 hyperplasia and thus correlated with Wntl tumor onset. Hh pathway repression is essential for embryonic mammary development and repression remains critical to homeostasis in the postnatal gland [37]. Pathway activation distorts mammary development, and is found in both epithelial and stromal compartments of human breast cancers [37,43-46]. Intriguingly, Gli1-lacZ is expressed within a minor subset of $\mathrm{p} 63^{+}$ basal cells in Wntl tumors and Ihh has been proposed to regulate proliferation of progenitors from stem cells via regulation of p63 isoform expression and to promote human mammosphere formation, considered to be a surrogate in vitro assay of stem cell proliferation $[47,48]$. However the most prominent site of $\mathrm{Hh}$ pathway activity in MMTV-Wntl mice occurs in stromal cells exclusively within the tumor microenvironment. Whether stromal Hh pathway activation is essential for breast tumor onset remains to be determined. However, the importance of this possibility has been underscored by a recent study showing an essential role for stromal Hh pathway activity in supporting tumor cell growth of xenografted pancreatic and colonic human cancers and cell lines [49]. Given that MMTV-Wntl tumors are enriched in cells with stem/progenitor characteristics, we speculate that stromal $\mathrm{Hh}$ pathway activity may be indicative of the step when CSCs co-opt bystanders to become complicit in tumor formation by forming a supportive CSG niche. Currently the relative importance of $\mathrm{Hh}$ pathway activity within epithelial and stromal compartments of tumors is a matter of heated debate [49,50]. As MMTV-Wntl tumors recapitulate the pattern of activity reported for human breast tumors they may provide as a useful genetic model to dissect the contribution of Hedgehog signaling within these different cell types to tumor onset and progression.

In summary our data show that Wntl and $\Delta$ N89 $\beta$-catenin generate distinct tumors at least in part through activating canonical signaling in distinct progenitors and through Wntspecific paracrine effects on multiple cell-types. Our data also show that Wnt 1 expression is linked with focal Hedgehog pathway activation in melanocytic nevi and mammary tumors. These data suggest Hh pathway activity and pigmentary changes may have utility as indicators of breast tumor onset induced by excess or unopposed Wnt ligand.

\section{Materials and Methods}

\section{Ethics Statement}

Animal maintenance and experimental procedures were in accordance with the NIH Guidelines for Animal Care and Use and were approved by the Institutional Animal Care and Use Committee of New York University Medical School.

\section{Mice}

MMTV-Wntl and MMTV- $\Delta$ N89 $\beta$-catenin mice were as described [13]. Axin2-d2EGFP, Conductin ${ }^{+/ l z}, \mathrm{Glil}^{+/ l z}, L_{t p b 1 L^{+/ l z}}$ were provided by Drs. Franke Costantini, Columbia University,
Alexandra Joyner, Sloan Kettering Institute and Velocigene, Regeneron Pharmaceuticals, Inc. [32,33,36,51].

\section{Mammary Whole Mount Staining}

To detect lacZ expression, mammary glands and tumors were fixed in $4 \%$ paraformaldehyde (PFA) in $1 \times$ phosphate buffered saline (PBS) (PFA; Sigma Aldrich, St. Louis, MO) for $1 \mathrm{~h}$, washed thrice in rinse buffer $\left(2 \mathrm{mM} \mathrm{MgCl}{ }_{2}, 0.1 \%\right.$ sodium deoxycholate, $0.2 \% \mathrm{NP} 40$ in PBS) for $1 \mathrm{~h}$ each and stained overnight at room temperature in X-gal staining solution $(50 \mathrm{mg} / \mathrm{ml}$ 5-bromo-4chloro-3-indolyl- $\beta$-D-galactopyranoside in rinse buffer containing $5 \mathrm{mM}$ potassium ferricyanide, $5 \mathrm{mM}$ potassium ferrocyanide) (Applichem, Cheshire, CT). After staining, glands and tumors were rinsed in $1 \times$ PBS, post-fixed in 4\% PFA overnight and processed for paraffin embedding. The tissues were sectioned, counterstained with Nuclear Fast Red (Polyscientific, Bay Shore, NY) and mounted for histological analyses. For whole mount analysis, X-gal stained mammary glands were counterstained with carmine, cleared and mounted as described http://mammary.nih.gov/tools/.

\section{Histology}

Tissues were either fixed in PFA and X-gal stained as described above or fixed in $10 \%$ phosphate buffered formalin overnight, then processed and embedded in paraffin. $4 \mu$ sections were deparaffinized with xylene (or citrosolve for X-gal stained tissue) and rehydrated through a graded series of ethanol. Citric acid antigen retrieval was performed for all antibodies by microwaving in $6.53 \mathrm{mM}$ sodium citrate $\mathrm{pH} 6.0$ for $30 \mathrm{~min}$ at 1.21 kilowatts. Rabbit antibodies against K14 (cat\# PRB155P, Covance, Berkeley, CA) (1:2000), MUC1 (1:500) (Abcam), laminin (1:100) (Sigma), S-100ß (1:4000)(Dako \#Z0311), mouse antibodies against K18 (cat\# 61028, Progen Biotechnik, Heidelberg, Germany), estrogen receptor (1:500) (DAKO, Carpinteria, CA), and guinea-pig anti-vimentin (1:1000)(Progen) were detected using biotin labeled secondary antibodies (Vector Labs, Burlingame, CA) $(1: 1000)$ in conjunction with streptavidin peroxidase (Fisher Scientific, Suwanne, GA) that was colorimetrically detected using diaminobenzidine (cat\# K3466, DakoCytomation, Carpinteria, CA). For S-100 $\beta$ staining, sections were subjected to antigen retrieval with $0.1 \%$ trypsin (Sigma \#T0303), $0.1 \% \mathrm{CaCl} 2$ in $50 \mathrm{mM}$ Tris-HCl, $\mathrm{pH} 7.6$ at $37^{\circ} \mathrm{C}$ for $45 \mathrm{~min}$ in a humidified chamber. Slides were washed continuously under running tap water for $5 \mathrm{~min}$ and processed for immunohistochemistry. Azure B staining was performed as described [52].

\section{Mammary Epithelial Cell Isolation and Flow Cytometry}

Mammary glands and tumors were minced and digested for 6 $7 \mathrm{~h}$ at $37^{\circ} \mathrm{C}$ in EpiCult-B Medium supplemented with $5 \%$ fetal bovine serum (FBS) containing $300 \mathrm{U} \mathrm{ml}^{-1}$ collagenase and $100 \mathrm{U} \mathrm{ml}^{-1}$ hyaluronidase. Digests were pipetted $8-12$ times and vortexed for 5 seconds every hour. After dissociation, cells were pelleted at $350 \times \mathrm{g}$ for $5 \mathrm{~min}$ and resuspended in a 1:4 mixture of Hanks' Balanced Salt Solution containing 2\% FBS (HF) and ammonium chloride and centrifuged again. Cell pellets were gently dissociated for $3 \mathrm{~min}$ in $5 \mathrm{ml}$ of pre-warmed $0.25 \%$ trypsinEDTA. $10 \mathrm{ml}$ of cold $\mathrm{HF}$ was added. Cells were pelleted by centrifugation and resuspended for $1 \mathrm{~min}$ in $5 \mathrm{mg} \mathrm{ml}^{-1}$ of prewarmed dispase II containing $0.1 \mathrm{mg} \mathrm{ml}^{-1}$ DNase I, then diluted with $10 \mathrm{ml}$ of cold $\mathrm{HF}$ and filtered through a $40-\mu \mathrm{m}$ mesh. All reagents were from StemCell Technologies Inc. [27]. All antibodies were purchased from BD Pharmingen unless otherwise noted. Cells at a concentration of $2.5 \times 10^{6}$ per $100 \mu \mathrm{l}$ of $2 \%$ bovine serum albumin (BSA) were incubated on ice for $30 \mathrm{~min}$ with primary antibodies: $0.5 \mathrm{ng} / \mathrm{ml}$ of biotinylated TER 119 (cat\# 
553672), CD31 (cat\# 558737), CD45 (553078), CD24-phycoerythrin (PE) (cat\# 553262), and $0.25 \mathrm{ng} / \mathrm{ml}$ of CD49f-allophycocyanin (APG) (cat\# FAB13501A, Minneapolis, MN, R\&D Systems). Cells were washed once in $200 \mu \mathrm{l} 2 \% \mathrm{BSA}$, stained with $1.5 \mathrm{ng} / \mathrm{ml}$ of streptavidin-Alexa488 on ice for $30 \mathrm{~min}$, washed again and resuspended in $2 \%$ BSA. $1 \mu \mathrm{g} / \mathrm{ml}$ of $7-$ aminoactinomycin D (7-AAD) (cat\# 00-6993-50, San Diego, CA, eBioscience) was added just prior to data acquisition. Flow cytometric data was acquired on a FACS Caliber cytometer at the NYU Skirball FACS Core Facility and analyzed using FlowJo software [27]

\section{Colony-Forming Assays}

NIH-3T3 cells were irradiated in suspension at 20Gy and seeded as a feeder layer $24 \mathrm{~h}$ prior to assay, at a concentration of $1.9 \times 10^{4}$ cells/well in 24-well plates (Corning Incorporated, Corning, NY). Lineage ${ }^{+}$cells were depleted prior to sorting using the EasySep Cell Biotin Selection Kit (StemCell Technologies Inc.) using TER119, CD31, and CD45 and CD140A (eBioscience) antibodies. $\mathrm{GFP}^{+}, \mathrm{GFP}^{-}$and Total Sorted tumor cells were sorted into $1 \mathrm{ml}$ of $100 \%$ FBS using a MoFlo cell sorter, excluding cell debris, cell doublets, and autofluorescent cells. Sorted cell populations were centrifuged at $350 \mathrm{~g}$ for $3 \mathrm{mins}$, resuspended

\section{References}

1. Gat U, Dasgupta R, Degenstein L, Fuchs E (1998) De novo hair follicle morphogenesis and hair tumors in mice expressing a truncated $\beta$-catenin in skin. Cell 95: 605-614.

2. Huelsken J, Vogel R, Erdmann B, Cotsarelis G, Birchmeier W (2001) betaCatenin controls hair follicle morphogenesis and stem cell differentiation in the skin. Cell 105: 533-545.

3. Malanchi I, Peinado H, Kassen D, Hussenet T, Metzger D, et al. (2008) Cutaneous cancer stem cell maintenance is dependent on beta-catenin signalling. Nature 452: 650-653.

4. Hatsell S, Rowlands T, Hiremath M, Cowin P (2003) Beta-catenin and Tcfs in mammary development and cancer. J Mammary Gland Biol Neoplasia 8: $145-158$.

5. Cowin P, Rowlands TR, Hatsell S (2005) Cadherins and Catenins in Breast Cancer. Current Opinions in Cell Biology in press.

6. Andl T, Reddy ST, Gaddapara T, Millar SE (2002) WNT signals are required for the initiation of hair follicle development. Dev Cell 2: 643-653.

7. van Genderen C, Okamura RM, Farinas I, Quo R-G, Parslow TG, et al. (1994) Development of several organs that require inductive epithelial-mesenchymal interactions is impaired in Lef-1 deficient mice. Genes and Development 8: 2691-2704.

8. Buhler TA, Dale TC, Kieback C, Humphreys RG, Rosen JM (1993) Localization and quantification of Wnt-2 gene expression in mouse mammary development. Developmental Biology 155: 87-96.

9. Lindvall C, Evans NC, Zylstra CR, Li Y, Alexander CM, et al. (2006) The Wnt signaling receptor Lrp5 is required for mammary ductal stem cell activity and Wnt1-induced tumorigenesis. J Biol Chem 281: 35081-35087.

10. Bradbury JM, Edwards PA, Niemeyer CG, Dale TC (1995) Wnt-4 expression induces a pregnancy-like growth pattern in reconstituted mammary glands in virgin mice. Dev Biol 170: 553-563.

11. Brisken C, Heineman A, Chavarra T, Elenbaas B, Tan J, et al. (2000) Essential function of Wnt-4 in mammary gland development downstream of progesterone signaling. Genes and Development 14: 650-654.

12. Roarty K, Serra R (2007) Wnt5a is required for proper mammary gland development and TGF-beta-mediated inhibition of ductal growth. Development 134: 3929-3939.

13. Imbert A, Eelkema R, Jordan S, Feiner H, Cowin P (2001) $\Delta$ N898-catenin induces precocious development, differentiation, and neoplasia in mammary gland. J Cell Biology 153: 555-568.

14. Hsu W, Shakya R, Costantini F (2001) Impaired mammary gland and lymphoid development caused by inducible expression of Axin in transgenic mice. J Cell Biol 155: 1055-1064

15. Tepera SB, McCrea PD, Rosen JM (2003) A beta-catenin survival signal is required for normal lobular development in the mammary gland. J Cell Sci 116 : 1137-1149.

16. Ugolini F, Charafe-Jauffret E, Bardou VJ, Geneix J, Adelaide J, et al. (2001) WNT pathway and mammary carcinogenesis: loss of expression of candidate tumor suppressor gene SFRP1 in most invasive carcinomas except of the medullary type. Oncogene 20: 5810-5817.

17. Tsukamoto A, Grosschedl R, Guzman R, Parslow T, Varmus H (1988) Expression of the int-1 gene in transgenic mice is associated with mammary in a $300 \mu \mathrm{l}$, assessed for viability in 50\% Trypan Blue and plated at limiting dilution. Media (EpiCultB+bullet, 5\% FBS, $100 \mathrm{U} / \mathrm{ml}$ Penicillin/Streptomycin, $1 \mu \mathrm{g} / \mathrm{ml}$ Ciprofloxacin, $0.25 \mu \mathrm{g} / \mathrm{ml}$ Fungizone) was changed $48 \mathrm{~h}$ later to medium lacking FBS. Colonies were fixed after 6 days in 50:50 acetone:methanol at $-20^{\circ} \mathrm{C}$ for $3 \mathrm{~min}$ and counted. Cells were stained with primary antibodies to K8 (Progen Cat\#65138) and K14 (1:2,000, Covance PRB-155P) for $30 \mathrm{~min}$, washed three times in PBS, stained with goat anti-mouse (1:100, Invitrogen Cat\#A11801) and donkey anti-rabbit (1:100, Chemicon Cat\#AP182C) followed by three washes in PBS.

\section{Acknowledgments}

We thank Irina Pechenkina for technical assistance and Peter Lopez, NYU Cancer Center FACS Core and Shane Meehan, Department of Dermatopathology for advice and assistance.

\section{Author Contributions}

Conceived and designed the experiments: PC. Performed the experiments: BT AP AI SH MH. Analyzed the data: BT AP AI SH PC. Wrote the paper: $\mathrm{PC}$.

gland hyperplasia and adenocarcinomas in male and female mice. Cell 55: 619-625.

18. Rowlands TM, Pechenkina IV, Hatsell SJ, Pestell RG, Cowin P (2003) Dissecting the roles of beta-catenin and cyclin D1 during mammary development and neoplasia. Proc Natl Acad Sci U S A 100: 11400-11405.

19. Li Y, Welm B, Podsypanina K, Huang S, Chamorro M, et al. (2003) Evidence that transgenes encoding components of the Wnt signaling pathway preferentially induce mammary cancers from progenitor cells. Proc Natl Acad Sci U S A 100: $15853-15858$

20. Liu BY, McDermott SP, Khwaja SS, Alexander CM (2004) The transforming activity of Wnt effectors correlates with their ability to induce the accumulation of mammary progenitor cells. Proc Natl Acad Sci U S A 101: 4158-4163.

21. Shackleton M, Vaillant F, Simpson KJ, Stingl J, Smyth GK, et al. (2006) Generation of a functional mammary gland from a single stem cell. Nature 439: 84-88.

22. Vaillant F, Asselin-Labat ML, Shackleton M, Forrest NC, Lindeman GJ, et al. (2008) The mammary progenitor marker CD61/beta3 integrin identifies cancer stem cells in mouse models of mammary tumorigenesis. Cancer Res 68: 7711-7717.

23. Al-Hajj M, Wicha MS, Benito-Hernandez A, Morrison SJ, Clarke MF (2003) Prospective identification of tumorigenic breast cancer cells. Proc Natl Acad Sci U S A 100: 3983-3988.

24. Chepko G, Smith GH (1997) Three division-competent, structurally-distinct cell populations contribute to murine mammary epithelial renewal. Tissue Cell 29: 239-253.

25. Welm BE, Tepera SB, Venezia T, Graubert TA, Rosen JM, et al. (2002) Sca1 (pos) cells in the mouse mammary gland represent an enriched progenitor cell population. Dev Biol 245: 42-56.

26. Alvi AJ, Clayton H, Joshi C, Enver T, Ashworth A, et al. (2003) Functional and molecular characterisation of mammary side population cells. Breast Cancer Res 5: R1-8.

27. Stingl J, Eirew P, Ricketson I, Shackleton M, Vaillant F, et al. (2006) Purification and unique properties of mammary epithelial stem cells. Nature 439: 993-997.

28. Asselin-Labat ML, Sutherland KD, Barker H, Thomas R, Shackleton M, et al (2007) Gata-3 is an essential regulator of mammary-gland morphogenesis and luminal-cell differentiation. Nat Cell Biol 9: 201-209.

29. Sleeman KE, Kendrick H, Robertson D, Isacke CM, Ashworth A, et al. (2007) Dissociation of estrogen receptor expression and in vivo stem cell activity in the mammary gland. J Ciell Biol 176: 19-26.

30. Villadsen R, Fridriksdottir AJ, Ronnov-Jessen L, Gudjonsson T, Rank F, et al. (2007) Evidence for a stem cell hierarchy in the adult human breast. J Cell Biol 177: $87-101$.

31. Barker N, van Es JH, Kuipers J, Kujala P, van den Born M, et al. (2007) Identification of stem cells in small intestine and colon by marker gene Lgr5. Nature 449: 1003-1007.

32. Lustig B, Jerchow B, Sachs M, Weiler S, Pietsch T, et al. (2002) Negative feedback loop of Wnt signaling through upregulation of conductin/axin2 in colorectal and liver tumors. Mol Cell Biol 22: 1184-1193.

33. Jho EH, Zhang T, Domon C, Joo CK, Freund JN, et al. (2002) Wnt/betacatenin/Tcf signaling induces the transcription of Axin2, a negative regulator of the signaling pathway. Mol Cell Biol 22: 1172-1183. 
34. Cho RW, Wang X, Diehn M, Shedden K, Chen GY, et al. (2008) Isolation and molecular characterization of cancer stem cells in MMTV-Wnt-1 murine breast tumors. Stem Cells 26: 364-371.

35. Yang S, Andl T, Gratchtchouk V, Wang A, Liu J, et al. (2008) Pathological responses to oncogenic Hedgehog signaling in skin are dependent on canonical Wnt/b-catenin signaling. Nature Genetics 40: 1130-1135.

36. Bai CB, Auerbach W, Lee JS, Stephen D, Joyner AL (2002) Gli2, but not Glil, is required for initial Shh signaling and ectopic activation of the Shh pathway. Development 129: 4753-4761.

37. Hatsell SJ, Cowin P (2006) Gli3-mediated repression of Hedgehog targets is required for normal mammary development. Development 133: 3661-3670.

38. Hiremath M, Lydon JP, Cowin P (2007) The pattern of beta-catenin responsiveness within the mammary gland is regulated by progesterone receptor. Development 134: 3703-3712.

39. Howe LR, Watanabe O, Leonard J, Brown AM (2003) Twist is up-regulated in response to Wnt 1 and inhibits mouse mammary cell differentiation. Cancer Res 63: 1906-1913.

40. Yanfeng W, Saint-Jeannet JP, Klein PS (2003) Wnt-frizzled signaling in the induction and differentiation of the neural crest. Bioessays 25: 317-325.

41. Matera I, Watkins-Chow DE, Loftus SK, Hou L, Incao A, et al. (2008) A sensitized mutagenesis screen identifies Gli3 as a modifier of Sox10 neurocristopathy. Hum Mol Genet 17: 2118-2131.

42. Stecca B, Mas C, Clement V, Zbinden M, Correa R, et al. (2007) Melanomas require HEDGEHOG-GLI signaling regulated by interactions between GLI1 and the RAS-MEK/AKT pathways. Proc Natl Acad Sci U S A 104: 5895-5900.

43. Moraes RC, Zhang X, Harrington N, Fung JY, Wu MF, et al. (2007) Constitutive activation of smoothened (Smo) in mammary glands of transgenic mice leads to increased proliferation, altered differentiation and ductal dysplasia. Development.

44. Lewis MT, Ross S, Strickland PA, Sugnet CW, Jimenez E, et al. (1999) Defects in mouse mammary gland development caused by conditional haploinsufficiency of Patched-1. Development 126: 5181-5193.

45. Fiaschi M, Rozell B, Bergstrom A, Toftgard R, Kleman MI (2007) Targeted expression of GLI1 in the mammary gland disrupts pregnancy-induced maturation and cause lactation failure. J Biol Chem.

46. Hatsell S, Frost AR (2007) Hedgehog signaling in mammary gland development and breast cancer. J Mammary Gland Biol Neoplasia 12: 163-173.

47. Li N, Singh S, Cherukuri P, Li H, Yuan Z, et al. (2008) Reciprocal intraepithelial interactions between TP63 and hedgehog signaling regulate quiescence and activation of progenitor elaboration by mammary stem cells. Stem Cells 26: 1253-1264.

48. Dontu G, Wicha MS (2005) Survival of mammary stem cells in suspension culture: implications for stem cell biology and neoplasia. J Mammary Gland Biol Neoplasia 10: 75-86.

49. Yauch RL, Gould SE, Scales SJ, Tang T, Tian H, et al. (2008) A paracrine requirement for hedgehog signalling in cancer. Nature 455: 406-410.

50. Ruiz i Altaba A (2008) Therapeutic Inhibition of Hedgehog-Gli Signaling in Cancer: pithelial, Stromal, or Stem Cell Targets. Cancer Cell 14: 281-283.

51. Todorovic V, Frendewey D, Gutstein DE, Chen Y, Freyer L, et al. (2007) Long form of latent TGF-beta binding protein 1 (LtbplL) is essential for cardiac outflow tract septation and remodeling. Development 134: 3723-3732.

52. Kamino H, Tam ST (1991) Immunoperoxidase technique modified by counterstain with azure $\mathrm{B}$ as a diagnostic aid in evaluating heavily pigmented melanocytic neoplasms. J Cutan Pathol 18: 436-439. 